\title{
PENGARUH METODE PAKEM TERHADAP HASIL BELAJAR SISWA PADA MATA PELAJARAN IPS MATERI KERAJAAN-KERAJAAN HINDU DI INDONESIA DENGAN MEMBUAT ALAT PERAGA WAYANG SEJARAH DI KELAS V SDN 116874 BAKARAN BATU KABUPATEN LABUHANBATU
}

\author{
Defa, Fauziah Desrini, Ifran Fredi Tarigan \\ Surel:devanyaaulyta@gmail.com
}

\begin{abstract}
Abstrak
Metode perbaikan pembelajaran ini adalah dengan metode PAKEM, yang berfokus pada siswa, guru tidak banyak berceramah di depan kelas. Tujuan penelitian ini adalah untuk membuktikan bahwa dengan metode PAKEM pada mata pelajaran IPS materi kerajaan- kerajaan Hindu di Indonesia, siswa tidak lagi mendengar ceramah dari guru di depan kelas dalam menerima pembelajaran tersebut. Melainkan siswa akan terjun langsung seperti halnya salah satu karakteristik kurikulum 2013 yaitu pembelajaran yang berpusat pada siswa. Pada materi ini, siswa akan membuat alat peraga murah, dari bahan- bahan sederhana yang disebut Wayang. Penelitian ini menggunakan pendekatan tindakan kelas. Judulnya " Pengaruh Metode PAKEM terhadap hasil belajar siswa pada mata pelajaran IPS materi kerajaan- kerajaan Hindu di Indonesia dengan membuat alat peraga wayang sejarah di kelas V SD No. 116874 Bakaran Batu ".Populasi penelitian diambil semua siswa kelas $V$, teknik pengumpulan data diperoleh dari hasil tes siswa. Tindakan dilakukan sebanyak dua siklus. Teknik analisis data digunakan analisis persentase dari perubahan hasil evaluasi belajar sebelum dan setelah dilakukan tes.
\end{abstract}

Kata kunci : PAKEM, Hasil Belajar, Alat Peraga Wayang Sejarah

\section{PENDAHULUAN}

Kurikulum adalah seperangkat rencana dan pengaturan mengenai tujuan, isi dan bahan pelajaran serta cara yang digunakan sebagai pedoman penyelenggara kegiatan pembelajaran untuk mencapai tujuan pendidikan tertentu. Kurikulum berakar pada budaya lokal dan bangsa memiliki arti bahwa kurikulum harus memberikan kesempatan kepada peserta didik untuk belajar dari budaya setempat dan nasional tentang berbagai nilai yang penting.

Dalam tujuan pendidikan nasional Pasal 3 UU N0. 20 Tahun 2003 bahwa Berkembangnya potensi peserta didik agar menjadi manusia yang beriman dan bertakwa kepada Tuhan Yang Maha Esa, berakhlak mulia, sehat, berilmu, cakap, kreatif, mandiri, dan menjadi warga negara yang demokratis serta bertanggung jawab, yaitu memiliki sikap spiritual, sosial, pengetahuan dan keterampilan.

Program PascasarjanaUniversitasNegeri Medan Program PascasarjanaUniversitasNegeri Medan Program PascasarjanaUniversitasNegeri Medan 
Dan dewasa ini Pendidikan di Indonesia telah merubah kurikulum yang sebelumnya KTSP menjadi Kurikulum 13, yang merupakan kurikulum baru dan masih melakukan revisi sebagai perbaikan pendidikan di Indonesia. Adapun tujuan dari kurikulum 13 yaitu untuk mempersiapkan manusia Indonesia agar memiliki kemampuan hidup sebagai pribadi dan warga negara yang beriman, produktif, kreatif, inovatif, dan afektif serta mampu berkontribusi pada kehidupan bermasyarakat, berbangsa, bernegara, dan peradaban dunia. Dan salah satu metode pembelajaran yang sesuai dengan kurikulum 13 yaitu metode PAKEM ( Pembelajaran aktif, kreatif, efektif dan menyenangkan ).

Salah satu mata pelajaran yang diterapkan di sekolah dasar adalah mata pelajaran IPS. IPS merupakan salah satu mata pelajaran yang dianggap sulit oleh siswa karena biasanya guru terlalu banyak berceramah. Sehingga siswa tidak tertarik dengan pembelajaran tersebut dimana pembelajaran berpusat pada guru. Siswa hanya disuruh mendengar dan memahami apa yang mereka dengar. Terkadang siswa mengantuk dan tidak fokus pada pembelajaran mereka.

Disini penulis tertarik untuk merubah cara belajar IPS dengan sesuatu yang berbeda yaitu menggunakan metode PAKEM. Pada pelajaran IPS materi Kerajaan- kerajaan Hindu di Indonesia, kali ini siswa tidak mendengarkan ceramah dari guru. Melainkan mereka belajar tentang materi tersebut dengan membuat sebuah alat peraga murah dan mempresentasikannya kedalam sebuah cerita sejarah yang disebut "Wayang Sejarah".

\section{Kurikulum}

Kurikulum adalah seperangkat rencana dan pengaturan mengenai tujuan, isi dan bahan pelajaran serta cara yang digunakan sebagai pedoman penyelenggara kegiatan pembelajaran untuk mencapai tujuan pendidikan tertentu. Kurikulum berakar pada budaya lokal dan bangsa memiliki arti bahwa kurikulum harus memberikan kesempatan kepada peserta didik untuk belajar dari budaya setempat dan nasional tentang berbagai nilai yang penting. Kurikulum juga harus memberikan kesempatan kepada peserta didik untuk berpartisipasi dalam mengembangkan nilai- nilai budaya setempat dan nasional menjadi nilai budaya yang digunakan dalam kehidupan sehari- hari dan menjadi nilai yang dikembangkan lebih lanjut untuk kehidupan masa depan. Hal ini sesuai dengan Kurikulum 2013 bertujuan untuk mempersiapkan manusia Indonesia agar memiliki kemampuan hidup sebagai pribadi dan warga negara yang beriman, produktif, kreatif, inovatif, dan afektif serta mampu berkontribusi pada kehidupan bermasyarakat, berbangsa, bernegara, dan peradaban dunia.

Pasal 1 UU No, 20/2003 tentang Sitem Pendidian Nasional menyatakan, “ Pendidikan adalah usaha sadar dan berencana untuk mewujudkan suasana belajar dan proses pembelajaran agar peserta didik secra aktif mengembangkan potensi dirinya untuk memiliki kekuatan spiritual keagamaan, pengendalian diri, kepribadian, kecerdasan, akhlak mulia serta keterampilan yang diperlukan dirinya, masyarakat, bangsa dan negara. 


\section{b. Alat peraga}

Pengertian Alat Peraga adalah semua atau segala sesuatu yang bisa digunakan dan dapat dimanfaatkan untuk menjelaskan konsep- konsep pembelajaran dari materi yang bersifat abstrak atau kurang jelas menjadi nyata dan jelas. Sehingga dapat merangsang pikiran, perasaan, perhatian serta minat para siswa yang menjurus kearah terjadinya proses belajar mengajar.

Alat peraga merupakan suatu alat yang dipakai untuk membantu dalam proses belajar mengajar yang berperan besar sebagai pendukung kegiatan belajarmengajar yang dilakukan oleh pengajar atau guru. Penggunaan alat peraga ini mempunyai tujuan untuk memberikan wujud yang riil terhadap bahan yang dibicarakan dalam materi pembelajaran. Alat peraga yang dipakai dalam proses belajar- mengajar dalam garis besarnya memiliki manfaat menambahkan kegiatan belajar para siswa, menghemat waktu belajar, memberikan alasan yang wajar untuk belajar, sebab dapat membangkitkan minat perhatian dan aktivitas para siswa.

\section{PAKEM}

Berikut pandangan dari para ahli mengenai kegiatan, siswa dan lingkungan belajar active learning yang dipaparkan oleh Missouri Department of Elementary and Secondary Education Missouri Department of Elementry and Secondary Education sebagai berikut ini:

Silberman, M (1996) menggambarkan saat belajar aktif, para siswa melakukan banyak kegiatan. Mereka menggunakan otak untuk mempelajari ide-ide, memecahkan permasalahan, dan menerapkan apa yang mereka belajar. belajar aktif adalah mempelajari dengan cepat, menyenangkan, penuh semangat, dan keterlibatan secara pribadi untuk mempelajari sesuatu dengan baik, harus mendengar, melihat, menjawab pertanyaan, dan mendiskusikannya dengan orang lain. Semua itu diperlukan oleh siswa untuk melakukan kegiatan - menggambarkannya sendiri, mencontohkan, mencoba keterampilan, dan melaksanakan tugas sesuai dengan pengetahuan yang telah mereka miliki.

Glasgow (1996) siswa aktif adalah siswa yang bekerja keras untuk mengambil tanggung jawab lebih besar dalam proses belajarnya sendiri. Mereka mengambil suatu peran yang lebih dinamis dalam memutuskan apa dan bagaimana mereka harus mengetahui, apa yang harus mereka lakukan, dan bagaimana mereka akan melakukan itu. Peran mereka kemudian semakin luas untuk self-management, dan memotivasi diri untuk menjadi suatu kekuatan lebih besar di yang dimiliki siswa.

\section{METODE PENELITIAN}

Dalam penelitian ini untuk mengukur hasil belajar siswa adalah dengan penilaian test. Dan dilakukan dalam 2 siklus untuk melaksanakan perbaikan pembelajaran. Pada siklus 1, metode yang digunakan adalah metode ceramah atau 
disebut metode klasikal. Sedangkan pada siklus 2, menggunakan metode PAKEM. Subjek Penelitian adalah seluruh siswa Kelas 5 di SD Negeri NO. 116874 Bakaran Batu Kecamatan Rantau Selatan Kabupaten Labuhanbatu yang terdiri dari 32 orang siswa dari 12 orang Laki- laki dan 20 orang Perempuan. Tingkat usia 11- 13 tahun.Penelitian ini dilakukan di Kelas Vc, SD Negeri NO. 116874 Bakaran Batu Kecamatan Rantau Selatan Kabupaten Labuhanbatu.Waktu Penelitian dimulai dari Bulan Januari 2017 sampai dengan Maret 2017 yang dilakukan pada semester genap.

Kegiatan penelitian ini dilakukan melalui 2 siklus. Dalam setiap siklus terdiri dari tahap yaitu:

Perencanaan

Tindakan

Observasi

Refleksi

Instrumen data nilai siswa

Teknik ini digunakan dengan mengumpulkan data- data nilai hasil belajar siswa pada pelajaran IPS materi kerajaan - kerajaan di Indonesia

Observasi

Teknik ini digunakan dengan observasi pada motivasi siswa dalam belajar dengan membuat alat peraga murah yang dibuat oleh masing masing siswa.

Wawancara

Teknik ini digunakan untuk mendapat informasi sejauh mana ketertarikan siswa dan kemampuan siswa dalam menerima materi pelajaran

Test

Test dilakukan setiap akhir siklus yang difungsikan untuk mengukur hasil belajar yang diperoleh siswa.

\section{HASIL PENELITIAN DAN PEMBAHASAN}

Pada perbaikan pembelajaran ini dilakukan dengan 2 siklus penelitian pembelajaran. Yaitu materi kerajaan- kerajaan Hindu di indonesia seperti kerajaan kutai, tarumanegara, kediri, mataram dan singosari.

\section{Siklus 1}

Pada perbaikan pembelajaran siklus 1, guru menggunakn metode ceramah dalam pembelajaran. Dimana setelah melakukan ceramah, siswa diminta untuk mendengar, kemudian menympulkan apa yang mereka dengar dan mereka pahami. Setelah itu, guru memberikan tes latihan soal yang berkaitan dengan materi untuk melihat hasil belajar siswa pada siklus 1 dengan menggunakan metode ceramah. 
Dari hasil tes tersebut pada siklus 1, mata pelajaran IPS materi kerajaankerajaan Hindu di Indonesia, dengan batas KKM yaitu 65. Jumlah siswa dari 32 siswa yang tuntas hanya 16 siswa dengan persentase sebesar 43,75\% sedangkan siswa yang tidak tuntas terdiri dari 18 orang siswa dengan persentasi 56,25\%. Untuk itu peneliti melakkan perbaikan pembelajaran siklus 2 untuk mendapatkan nilai ketuntasan sesuai batas KKM yang diharapkan.

\section{b. Siklus 2}

Pada siklus 2, peneliti melakukan penelitian tentang perbaikan pembelajaran mata pelajaran IPS materi kerajaan - kerajaan di Indonesia dengan metode PAKEM. Siswa tidak lagi berceramah di depan kelas, melainkan siswa dibagi dalam 5 kelompok kerajaan. Kemudian guru membagi suber belajar dengan buku, sumber internet dll. Disini siswa membaca cerita sejarah, berdiskusi kelompok dan membuat kesimpulan. Kemudian siswa perkelompok membuat alat peraga murah dari bahan- bahan sederhana untuk membuat tokoh- tokoh karakter wayang dalam cerita beserta dengan penunjang lainnya. Setelah selesai, siswa perkelompok untuk mempresentasikan hasil cerita wayang sejarah tersebut di depan kelas, sedangkan kelompok yang lain mendengar dan mencatat hal yang penting dari sebuah cerita yang dimainkan seperti dalang dengan wayangnya. Kelompok yang maju memainkan cerita kerajaan hindu dengan gaya bahasa mereka yang membuat siswa- siswa lain tertarik dengan wayang sejarah tersebut, sehingga suasana belajar terlihat menyenangkan.

Di akhir pembelajaran, seluruh siswa secara individu menuliskan kembali/ membuat kesimpulan dari masing- masing kerajaan yang telah mereka mainkan dan mereka tonton peragaan wayang sejarah oleh teman - temannya. Guru dan siswa bertanya jawab dan membuat kesimpulan. Dan untuk tes, guru memberikan soal yang berhubungan dengan materi kerajaan- kerajaan hindu di Indonesia.

Pada penilaian akhir siklus ke 2, dari jumlah siswa 32 orang. Dan hasilnya 32 orang siswa tersebut telah memenuhi nilai KKM. Seluruh siswa mendapat nilai tuntas pada materi kerajaan - kerajaan di Indonesia.Sehingga pada perbaikan pembelajaran ini, hanya dilakukan dalam 2 siklus saja.

\section{SIMPULAN}

Belajar adalah suatu kegiatan yang menghasilkan perubahan tingkah laku yang relatif permanen yang meliputi pengetahuan, nilai, sikap serta keterampilan sebagai hasil pengalaman, latihan dan interaksi dengan lingkungannya.

Perkembangan pembelajran IPS dilaksanakan dua siklus perbaikan dengan fokus perbaikan rendahnya hasil belajar siswa untuk memperbaiki pembelajaran pada masalah tersebut adalah penggunaan model pembelajaran "Wayang Sejarah" dapat memotivasi keinginan siswa untuk belajar, membuat siswa tidak bosan dalam pembelajaran, Aktif, Kreatif dan Efektif.

Sehubungan dengan hal tersebut di atas perbaikan pembelajaran pada siklus I dapat diketahui adanya sedikit peningkatan tetapi masih belum 
memuaskan karena tingkat keaktifan siswa dalam proses pembelajaran kurang memuaskan, yaitu siswa yang aktif baru mencapai 16 dari 32 siswa atau 43,75\% sedangkan siswa yang memperoleh nilai kurang dari 65 ada 18 atau 56,26\%. Pada siklus II sudah tampak adanya peningkatan keaktipan siswa. Hal ini terlihat dari hasil belajar siswa pada siklus II sudah banyak mengalami kemajuan, dimana 100\% siswa mendapat nilai memenuhi KKM dengan rata - rata kelas 80,28\% .

Dari penjelasan di atas sangat jelas betapa berpengaruhnya penerapan model pembelajaran Wayang Sejarah karena dapat meningkatkan keaktipan dan pemahaman siswa pada Pelajaran IPS materi Sejarah Kerajaan- kerajaan Hindu di Indonesia di kelas Vc SD Negeri No. 116874 Bakaran Batu Kecamatan Rantau Selatan Kabupaten Labuhanbatu.

\section{DAFTAR RUJUKAN}

Arikunto,s. (2002). Prosedur Penelitian Suatu Pendekatan Praktek. Jakarta : Rineka Cipta. Deperteman Pendidikan Nasional. (2003). Undang-undang Nomor 20 Tahun 2003 Tentang Sistem Pendidikan Nasional. Jakarta : Depdiknas.

Departemen Pendidikan Nasional. (2003). Metode Penelitian Tindakan Kelas. Jakarta:

Depdiknas.

Depdikbud, 1995. Kurikulum SD tahun 1994. Jakarta : Depdikbud.

Direktorat Jenderal Pendidikan Dasar dan Menengah. 2016. Materi Umum dan Materi Pokok Sekolah dasar.

Kementrian Pendidikan dan Kebudayaan Direktorat Jenderal Pendidikan Dasar dan Menengah. 2016. Panduan Teknis Pembelajaran dan Penilaian Di Sekolah Dasar.

Kementrian Pendidikan dan Kebudayaan. 2013. Kurikulum 2013.

Muhibbin Syah, 2004. Psikologi Pendidikan dengan Pendekatan Baru. Bandung Remaja Rosda Karya.

Ngalim Purwanto, 2004. Psikologi Pendidikan. Bandung: Remaja Rosda Karya.

Rochiati Wiriaatmadja, 2007. Metode Penelitian Tindakan Kelas Untuk Meningkatkan Kinerja Guru dan Dosen. Bandung : Remaja Rosdakarya.

Sapriya. 2009. Pendidikan IPS. Bandung: PT. Remaja Rosdakarya Offset.

Suyadi. 2012. Buku Panduan guru profesional Penelitian Tindakan Kelas (PTK) dan Penelitian Tindakan Sekolah (PTS). Yogyakarta : Penerbit Andi. 